\title{
Extended Numerical Taxonomy Study of Nocardia
}

\author{
M. TSUKAMURA \\ The National Chubu Hospital, Obu, Aichi, Japan 474
}

\begin{abstract}
Numerical classification of 80 strains received as Nocardia using six different sets of characters was carried out. A set of 57 "differentiating" characters gave six distinct clusters: Nocardia farcinica, $N$. asteroides A, $N$. asteroides $\mathrm{B}, N$. caviae, N. brasiliensis, and Gordona lentifragmenta (formerly, N. rubra). Hence, the strains received as $N$. asteroides were divided into three subgroups, $N$. farcinica, $N$. asteroides A, and N. asteroides B. The cluster of $G$. lentifragmenta was placed apart from the others, and a previous classification of this taxon as a species of Gordona was supported by the present study. The problem of a minimum number of differentiating characters necessary for numerical classification, which was considered theoretically as above 40 or 50, was studied experimentally in this study. The results supported the theoretical considerations. Inclusion of linked characters reduced the number of clusters.
\end{abstract}

Previous studies on the taxonomy of Nocardia were made by Gordon and Mihm (6-9) by use of physiological and biochemical characters. Many species were merged into a few species. Gordon and Mihm $(6,8)$ included the strain ATCC 3318, labeled as Nocardia farcinica, in the species Nocardia asteroides. The first numerical classification of Nocardia was carried out by Cerbón (3). He suggested that the species $N$. asteroides be divided into several subgroups. Subsequently, Tsukamura (22) carried out a numerical classification of Nocardia using a large number of characters and reported that the strains received as $N$. asteroides were divided into two distinct taxa. In this study, the strain ATCC 3318 of $N$. farcinica was included in one cluster. Hence, this cluster was named $N$. farcinica and another cluster was designated $N$. aster. oides. These two taxa could be differentiated by several characters. The former grew at $45^{\circ} \mathrm{C}$, showed acetamidase and benzamidase activities, formed acid from rhamnose, and utilized 1,3butylene glycol as sole carbon source and acetamide and monoethanolamine as simultaneous nitrogen and carbon sources; the latter taxon did not. This finding was supported by Berd (1), Holm (10), and Franklin and McClung (4) by use of the same phenetic analysis, and by Bradley (2) and Franklin and McClung (4) by use of a deoxyribonucleic acid hybridization technique. Magnusson and Mariat (14) suggested that, by using a delayed type skin reaction, $M$. farcinica be separated from $N$. asteroides.

At a later date, Goodfellow (5) and Kurup and Schmitt (11) reported that the species $N$. asteroides is divided into five and four subgroups, respectively. Goodfellow used none of the same strains as used by Tsukamura (22), and Kurup and Schmitt stated that one of their subgroups was identical to Tsukamura's $N$. farcinica.

The present study was carried out for two reasons: (i) to reinvestigate the heterogeneity of $N$. asteroides by use of a new set of characters which included several characters not used previously, and (ii) to observe the relationship between the clustering and the characters used in the study. Furthermore, the study was carried out to observe how many characters are needed to obtain a suitable clustering. Based on theoretical considerations, Sokal and Sneath (18) and Sneath (16) recommended the use of at least 50 to 60 characters, and Lockhart (13) recommended a minimum of about 40 for numerical classifications. In the present study, these recommendations were tested experimentally.

\section{MATERIALS AND METHODS}

The 80 strains used are listed in Table 1 . The names $N$. asteroides and $N$. farcinica were used according to the definition of the previous study (22). Lechevalier et al. (12) and Ridell and Norlin (15) questioned the authenticity of the strain ATCC 3318 of $N$. farcinica and claimed that the name $N$. farcinica was a nomen dubium.

The sets of characters used for numerical classifications are shown in Tables 2 and 3 . The set of characters shown in Table 2 was used for analysis of the relationship among Mycobacterium, Gordona, and Nocardia (23). Only 57 of these characters were effective for differentiation between Nocardia strains (omitting strain 71, which is now identified as Mycobacterium intracellulare). The number of "differentiating" characters in other sets, too, were calculated omitting this strain.

The matching coefficient (M-value) was calculated as described previously (24). Dendrograms were pre- 
TABLE 1. List of strains used in this study

\begin{tabular}{|c|c|c|c|c|c|}
\hline \multirow{2}{*}{$\begin{array}{l}\text { No. in } \\
\text { this } \\
\text { study }\end{array}$} & \multirow{2}{*}{$\begin{array}{l}\text { Labora- } \\
\text { tory no. }\end{array}$} & \multirow{2}{*}{ Identified as ${ }^{a}:$} & \multicolumn{3}{|c|}{ Received as: } \\
\hline & & & Name & Strain & Source $^{b}$ \\
\hline 1 & 23001 & Nocardia rubra & N. globerula & M75 & 1 \\
\hline 2 & 23002 & Gordona lentifragmenta & N. rubra & M1 & 1 \\
\hline 4 & 23004 & N. farcinica & $N$. asteroides & M72 & 1 \\
\hline 5 & 23005 & N. caviae & N. asteroides & M73 & 1 \\
\hline 6 & 23006 & N. asteroides & N. asteroides & M93 & 1 \\
\hline 7 & 23007 & N. asteroides & N. asteroides & M94 & 1 \\
\hline 9 & 23009 & N. asteroides & N. asteroides & M124 & 1 \\
\hline 10 & 23010 & N. farcinica & N. asteroides & M126 & 1 \\
\hline 11 & 23011 & N. farcinica & $N$. asteroides & M128 & 1 \\
\hline 12 & 23012 & N. asteroides & N. brasiliensis & M145 & 1 \\
\hline 13 & 23013 & N. farcinica & N. brasiliensis & M146 & 1 \\
\hline 16 & 23016 & G. lentifragmenta & N. rubra & M1 & 2 \\
\hline 18 & 23018 & N. rubra & N. globerula & M75 & 2 \\
\hline 21 & 23021 & G. lentifragmenta & N. minima & M103 & 2 \\
\hline 22 & 23022 & G. lentifragmenta & N. coeliaca & M122 & 2 \\
\hline 23 & 23023 & N. rubra & N. coeliaca & M191 & 2 \\
\hline 24 & 23024 & G. lentifragmenta & N. lutea & M192 & 2 \\
\hline 25 & 23025 & N. farcinica & N. madurae & $\mathrm{C} 407$ & 2 \\
\hline 27 & 23027 & N. farcinica & N. madurae & C743 & 2 \\
\hline 30 & 23030 & N. rubra & N. polychromogenes & M6 & 2 \\
\hline 31 & 23031 & $?$ & $\begin{array}{l}\text { Proactinomyces restric- } \\
\text { tus }\end{array}$ & M9 & 2 \\
\hline 32 & 23032 & N. asteroides & N. asteroides & M10 & 2 \\
\hline 33 & 23033 & N. caviae & N. caviae & M54 & 2 \\
\hline 34 & 23034 & N. farcinica & N. asteroides & M72 & 2 \\
\hline 35 & 23035 & N. caviae & N. asteroides & M73 & 2 \\
\hline 38 & 23038 & N. asteroides & N. asteroides & M93 & 2 \\
\hline 39 & 23039 & N. asteroides & N. asteroides & M94 & 2 \\
\hline 40 & 23040 & N. farcinica & N. asteroides & M111 & 2 \\
\hline 41 & 23041 & N. farcinica & N. eppingeri & M112 & 2 \\
\hline 44 & 23044 & N. asteroides & N. asteroides & $\mathrm{M} 124$ & 2 \\
\hline 45 & 23045 & N. asteroides & N. asteroides & M128 & 2 \\
\hline 46 & 23046 & N. asteroides & N. asteroides & M129 & 2 \\
\hline 48 & 23048 & N. farcinica & N. asteroides & M131 & 2 \\
\hline 49 & 23049 & N. asteroides & N. asteroides & M132 & 2 \\
\hline 51 & 23051 & N. farcinica & N. asteroides & M138 & 2 \\
\hline 53 & 23053 & N. farcinica & $N$. asteroides & M144 & 2 \\
\hline 54 & 23054 & N. asteroides & $N$. brasiliensis & M145 & 2 \\
\hline 55 & 23055 & N. farcinica & N. brasiliensis & M146 & 2 \\
\hline 56 & 23056 & N. asteroides & N. asteroides & M155 & 2 \\
\hline 57 & 23057 & N. asteroides & N. asteroides & M156 & 2 \\
\hline 58 & 23058 & N. farcinica & N. asteroides & M158 & 2 \\
\hline 59 & 23059 & N. farcinica & N. asteroides & M86 & 2 \\
\hline 60 & 23060 & N. farcinica & N. asteroides & M127 & 2 \\
\hline 62 & 23062 & N. farcinica & N. asteroides & $\mathrm{M} 158 \mathrm{~A}$ & 2 \\
\hline 65 & 23065 & N. farcinica & N. asteroides & M162 & 2 \\
\hline 66 & 23066 & N. asteroides & N. asteroides & M163 & 2 \\
\hline 67 & 23067 & N. farcinica & N. asteroides & M164 & 2 \\
\hline 69 & 23069 & N. farcinica & N. asteroides & M167 & $\overline{2}$ \\
\hline 70 & 23070 & N. farcinica & N. brasiliensis & M169 & 2 \\
\hline 71 & 23071 & $\begin{array}{l}\text { Mycobacterium intracel } \\
\quad \text { lulare }\end{array}$ & N. intracellularis & M170 & 2 \\
\hline 73 & 23073 & N. farcinica & N. asteroides & M175 & 2 \\
\hline 74 & 23074 & N. farcinica & N. asteroides & M177 & 2 \\
\hline 75 & 23075 & N. farcinica & N. asteroides & M179 & 2 \\
\hline 77 & 23077 & ? & N. asteroides & M181 & 2 \\
\hline 78 & 23078 & N. caviae & N. asteroides & M185 & 2 \\
\hline 81 & 23081 & N. farcinica & $N$. brasiliensis & M197 & 2 \\
\hline 82 & 23082 & N. farcinica & $N$. brasiliensis & M198 & 2 \\
\hline
\end{tabular}


TABIE 1. Continued

\begin{tabular}{|c|c|c|c|c|c|}
\hline \multirow{2}{*}{$\begin{array}{l}\text { No. in } \\
\text { this } \\
\text { study }\end{array}$} & \multirow{2}{*}{$\begin{array}{l}\text { Labora- } \\
\text { tory no. }\end{array}$} & \multirow{2}{*}{ Identified as ${ }^{a}$ : } & \multicolumn{3}{|c|}{ Received as: } \\
\hline & & & Name & Strain & Source \\
\hline 83 & 23083 & N. brasiliensis & N. brasiliensis & M199 & 2 \\
\hline 84 & 23084 & N. farcinica & $N$. brasiliensis & M201 & 2 \\
\hline 85 & 23085 & $?$ & N. tenuis-convoluta & M203 & 2 \\
\hline 86 & 23086 & N. brasiliensis & N. brasiliensis & M204 & 2 \\
\hline 87 & 23087 & N. farcinica & N. asteroides & M205 & 2 \\
\hline 88 & 23088 & N. asteroides & N. asteroides & M206 & 2 \\
\hline 92 & 23092 & N. farcinica & N. asteroides & M189 & 2 \\
\hline 93 & 23093 & N. farcinica & N. brasiliensis & $\mathrm{M} 200$ & 2 \\
\hline 95 & 23095 & N. asteroides & N. asteroides & $\mathrm{R} 443(1)$ & 3 \\
\hline 97 & 23097 & N. asteroides & N. asteroides & $\mathrm{R} 553$ & 3 \\
\hline 98 & 23098 & N. farcinica & N. asteroides & $\mathrm{R} 784$ & 3 \\
\hline 101 & 23101 & N. farcinica & N. asteroides & W3409B & 3 \\
\hline 102 & 23102 & N. farcinica & N. asteroides & $\begin{array}{l}\text { R3318 } \\
\quad \text { (ATCC3318) }\end{array}$ & 3 \\
\hline 103 & 23103 & N. asteroides & N. asteroides & ATCC9970 & 3 \\
\hline 104 & 23104 & $N$. brasiliensis & N. brasiliensis & $\mathrm{R} 405$ & 3 \\
\hline 105 & 23105 & $N$. brasiliensis & N. brasiliensis & $\mathrm{R} 432$ & 3 \\
\hline 106 & 23106 & N. brasiliensis & $N$. brasiliensis & R887 & 3 \\
\hline 108 & 23108 & N. brasiliensis & N. brasiliensis & $\mathrm{R} 1117 \mathrm{~A}$ & 3 \\
\hline 109 & 23109 & N. brasiliensis & N. brasiliensis & $\mathrm{R} 1188$ & 3 \\
\hline 111 & 23111 & N. caviae & N. caviae & $\mathrm{R} 416$ & 3 \\
\hline 112 & 23112 & N. caviae & N. caviae & $\mathrm{R} 547$ & 3 \\
\hline 113 & 23113 & N. caviae & N. caviae & $\mathrm{R} 617$ & 3 \\
\hline 114 & 23114 & N. caviae & N. caviae & R1291 & 3 \\
\hline
\end{tabular}

"All Nocardia strains, except for numbers 10, 12, 54, and 66, were identified in a previous study (22). Gordona strains were identified in another study (26). These were once identified as $N$. rubra (22).

${ }^{b} 1$, I. Uesaka, Kyoto University, Kyoto, Japan (received in 1965); 2, I. Uesaka, Kyoto University, Kyoto, Japan (received in 1967); 3, R. E. Gordon, Rutgers State University, New Brunswick, N.J. The strains received from I. Uesaka belonged to the collection of N. M. McClung, University of South Florida, Tampa, Fla., from whom I. Uesaka received the strains in 1960. The history of the strains, except for M126, M145 and M163, were described previously in detail (22). M126: I.Uesaka; N. M. McClung; R. E. Gordon; NCTC; S. 'T. Cowan; N. Conant. M145: I. Uesaka; N. M. McClung; McMillan (D-410); Gonzales-Ochoa. M163: I. Uesaka; N. M. McClung; J. D. Schneidau; University of Minnesota (Henrici's strain no. A10A, var. gypsoides).

pared by the single-linkage method (18). The computer used was IBM-S370 model 135, which is located in the Nagoya Factory, the Sumitomo Machinery Co., Obu, Aichi, Japan. The program was written in English (CŌBŌL) (no. G90002).

The data for the original "strain $\times$ characters" matrix have been deposited with the World Data Centre for Microorganisms, Brisbane, Australia. The data are available to anyone wishing to examine them by any other methods.

\section{RESULTS}

The data are shown in Fig. 1 to 6 as dendrograms.

The dendrogram obtained by set A1 (Fig. 1) shows six well-defined clusters, which correspond to N. farcinica, Nocardia brasiliensis, Nocardia caviae, $N$. asteroides $\mathrm{A}, N$. asteroides $\mathrm{B}$, and Gordona lentifragmenta. N. asteroides was divided into two clusters. Hence, the strains originally designated as $N$. asteroides when received were divided into three clusters, $N$. far cinica, $N$. asteroides A, and $N$. asteroides B. $G$. lentifragmenta, formerly named N. rubra, was placed apart from the others, forming a distinct cluster.

The dendrogram obtained by set A2 (Fig. 2) showed similar clusters to those obtained by set A1. The dendrogram obtained by set A3 (Fig. 3 ), in which the same number of differentiating characters as used in set A2, but different characters, were included, showed five clusters, all $N$. asteroides strains being combined into one.

The dendrogram obtained by set A4 (Fig. 4) showed only three clusters, which closely corresponded to N. farcinica, N. caviae, and G. lentifragmenta.

The dendrogram obtained by set A5 (Fig. 5) showed five clusters, which roughly corresponded to $N$. farcinica, $N$. caviae, $N$. brasiliensis, $N$. asteroides, and G. lentifragmenta. Several strains of $N$. asteroides were included in the cluster of $N$. farcinica.

The dendrogram obtained by set B (Fig. 6) showed five clusters, which approximately cor- 
TABLE 2. List of characters used in set $A 1^{a}$

\author{
1. Strong acid fastness \\ 2. Weak or partial acid fastness \\ 3. Rod shape \\ 4. Cord or compact grouping \\ 5. Fragmenting mycelium \\ 6. Permanent mycelium \\ 7. Rough colonies \\ 8. Colony pigmentation in dark \\ 9. Photochromogenicity \\ 10. Growth after 3 days \\ 11. Tolerance to $0.1 \% \mathrm{NaNO}_{2}$ \\ 12. Tolerance to $0.2 \%$ picric acid \\ 13. Growth on rifampin medium $(25 \mu \mathrm{g} / \mathrm{ml})$ \\ 14. Growth on $p$-aminosalicylic acid medium $(2 \mathrm{mg} / \mathrm{ml})$ \\ 15. $\mathrm{NH}_{2} \mathrm{OH} \cdot \mathrm{HCl}$ medium $(0.125 \mathrm{mg} / \mathrm{ml})$ \\ 16. $\mathrm{NH}_{2} \mathrm{OH} \cdot \mathrm{HCl}$ medium $(0.25 \mathrm{mg} / \mathrm{ml})$ \\ 17. $\mathrm{NH}_{2} \mathrm{OH} \cdot \mathrm{HCl}$ medium $(0.5 \mathrm{mg} / \mathrm{ml})$ \\ 18. Growth on TCH medium $(10 \mu \mathrm{g} / \mathrm{ml})$ \\ 19. Salicylate medium $(0.5 \mathrm{mg} / \mathrm{ml})$ \\ 20. $p$-Nitrobenzoic acid medium $(0.5 \mathrm{mg} / \mathrm{ml})$ \\ 21. Niacin \\ 22. Tween hydrolysis ( 7 days) \\ 23. Tween hydrolysis (14 days) \\ 24. $\alpha$-Esterase \\ 25. $\beta$-Esterase \\ 26. Acid phosphatase \\ 27. Catalase (semiquantitative) \\ 28. $\beta$-Galactosidase \\ 29. Nitrate reduction $(24 \mathrm{~h})$ \\ 30. Three-day arylsulfatase \\ 31. Two-week arylsulfatase \\ 32. Salicylate degradation \\ 33. $p$-Aminosalicylic acid degradation \\ 34. Acetamidase \\ 35. Benzamidase \\ 36. Urease \\ 37. Isonicotinamidase \\ 38. Nicotinamidase \\ 39. Pyrazinamidase \\ 40. Salicylamidase \\ 41. Allantoinase \\ 42. Succinamidase \\ 43. Growth at $28^{\circ} \mathrm{C}$ \\ 44. Growth at $37^{\circ} \mathrm{C}$ \\ 45. Growth at $45^{\circ} \mathrm{C}$
}

46. Growth at $52^{\circ} \mathrm{C}$

47. Glucose as C source

48. Mannose as C source

49. Sucrose as $\mathrm{C}$ source

50. $n$-Propanol as $\mathrm{C}$ source

51. $n$-Butanol as C source

52. Isobutanol as $\mathrm{C}$ source

53. Propylene glycol as C source

54. Galactose as C source

55. Arabinose as C source

56. Xylose as $\mathrm{C}$ source

57. Rhamnose as $\mathrm{C}$ source

58. Trehalose as $\mathrm{C}$ source

59. Inositol as $\mathrm{C}$ source

60. Mannitol as C source

61. Sorbitol as C source

62. Acetate as C source

63. Citrate as $\mathrm{C}$ source

64. Succinate as C source

65. Malate as $\mathrm{C}$ source

66. Pyruvate as $\mathrm{C}$ source

67. Benzoate as $\mathrm{C}$ source

68. Malonate as C source

69. Fumarate as $\mathrm{C}$ source

70. Acid from glucose

71. Acid from mannose

72. Glucose as C source (glutamate-N)

73. Acetate as $\mathrm{C}$ source (glutamate-N)

74. Succinate as C source (glutamate-N)

75. Pyruvate as $\mathrm{C}$ source (glutamate-N)

76. Glycerol as $\mathrm{C}$ source (glutamate-N)

77. Glutamate as $\mathrm{N}$ and $\mathrm{C}$ source

78. L-Serine as $\mathrm{N}$ and $\mathrm{C}$ source

79. Glucosamine as $\mathrm{N}$ and $\mathrm{C}$ source

80. Acetamide as $\mathrm{N}$ and $\mathrm{C}$ source

81. Benzamide as $\mathrm{N}$ and $\mathrm{C}$ source

82. Monoethanolamine as $\mathrm{N}$ and $\mathrm{C}$ source

83. Trimethylene diamine as $\mathrm{N}$ and $\mathrm{C}$ source

84. Benzamide as $\mathrm{N}$ source

85. Nicotinamide as $\mathrm{N}$ source

86. Nitrate as $\mathrm{N}$ source

87. Nitrite as $\mathrm{N}$ source

88. Ethambutol medium $(5 \mu \mathrm{g} / \mathrm{ml})$

89. 1,3-Butylene glycol as C source

90. 2,3-Butylene glycol as C source

${ }^{a}$ The references of the characters, except for characters 89 and 90 , are described in a previous paper (24). Characters 89 and 90 were described previously $(19,20)$. 
responded to $N$. farcinica, $N$. asteroides, $N$. caviae, $N$. brasiliensis, and $G$. lentifragmenta. In this dendrogram, the strains of $N$. asteroides B were included in the cluster of $N$. farcinica (compare Fig. 1 and Fig. 6).

"Distinguishing" characters useful for differentiation between the clusters obtained by set A1, which gave the most clusters, are shown in Table 4. In this table, characters of the strains that formed a compact cluster are shown. The clusters of $N$. farcinica, N. caviae, N. brasiliensis, $N$. asteroides $\mathrm{A}, N$. asteroides $\mathrm{B}$, and $G$. lentifragmenta were formed by $93,94,92,91,91$, and $94 \%$ levels, respectively (Fig. 1).

\section{DISCUSSION}

By comparing the dendrograms obtained by six different sets of characteristics, it is obvious that sets A1 and A2 provided the most clusters. Only these sets could divide $N$. asteroides strains (according to Tsukamura's definition [22]) into two subgroups. From the theoretical basis, Sokal and Sneath (18) stated that the number of differentiating characters for numerical classifications should be not less than 60 , Sneath (16) suggested at least 50, and Lockhart (13) specified above a minimum of about 40 . As sets $\mathrm{A} 1$ and $\mathrm{A} 2$ contained 57 and 40 differentiating characters, respectively, the theoretical considerations were shown experimentally to be correct.

Although set B contained 79 differentiating characters, it failed to give the most clusters. Sneath $(17)$ and Tsukamura $(19,25)$ stated that the characters for numerical classifications should not contain linked characters. Linked characters which are controlled by the same cistron should be ignored. Set $B$ contained the characters of the utilization of carbohydrates and those of acid formation from the same carbohydrates. The utilization of carbohydrates and the acid formation from them usually showed the same results. Probably based on the use of the linked characters, set B confused the $N$. asteroides B group with the $N$. farcinica group.

Sets A2 and A3 contained the same number of differentiating characters, but set A3 failed to differentiate between $N$. asteroides $\mathrm{A}$ and $\mathrm{B}$. It is suggested that, when the minimum number according to Lockhart (13) is used, the kind of characters may influence the clustering. Set A3 consisted of the characters concerned only with amidases and nutritional requirements, whereas set A2 consisted of various characters. Our results show that the use of various characters is better. Set A1, which contains 57 differentiating characters, is an improved set in which the num-
TABI.E 3. Sets of characters used in numerical classification

\begin{tabular}{lccc}
\hline Set & Characters & $\begin{array}{c}\text { No. of char- } \\
\text { acters }\end{array}$ & $\begin{array}{c}\text { No. of differen- } \\
\text { tiating charac- } \\
\text { ters }\end{array}$ \\
\hline A1 & $1-90^{b}$ & 90 & $57^{d}$ \\
A2 & $1-64^{b}$ & 64 & 40 \\
A3 & $35-90^{b}$ & 56 & 40 \\
A4 & $1-53^{b}$ & 53 & 30 \\
A5 & $51-90^{b}$ & 40 & 30 \\
B & $1-105^{c}$ & 105 & $79^{e}$ \\
\hline
\end{tabular}

"The number of differentiating characters was counted omitting strain 71 , which was identified as Mycobacterium intracellulare.

${ }^{b}$ See Table 2.

"From the 90 characters shown in Table 2, the following 7 characters were removed: no. 22 (Tween hydrolysis after 7 days); no. 72 (glucose as $\mathrm{C}$ source, glutamate- $\mathrm{N}$ ); no. 73 (acetate as $\mathrm{C}$ source, glutamate$\mathrm{N}$ ); no. 74 (succinate as C source, glutamate-N); no. 75 (pyruvate as $\mathrm{C}$ source, glutamate- $\mathrm{N}$ ); no. 76 (glycerol as C source, glutamate-N); and no. 88 (resistance to ethambutol). To the remaining 83 characters, the following 22 characters were added (19-21): (1) Gram positiveness; (2) growth on $\mathrm{NH}_{2} \mathrm{OH} \cdot \mathrm{HCl}(62.5 \mu \mathrm{g} / \mathrm{ml})$; (3) growth on salicylate medium $(1.0 \mathrm{mg} / \mathrm{ml})$; (4) tolerance to $0.1 \%$ picric acid; (5) tolerance to $0.2 \% \mathrm{NaNO}_{2}$; (6) growth on $1 \%$ Tween-Sauton agar; (7) malonamidase; (8) fructose as C source; (9) glycerol as C source; (10) ethanol as C source; (11) 1,4-butylene glycol as C source; (12) raffinose as C source; (13) acid from raffinose; (14) acid from galactose; (15) acid from arabinose; (16) acid from xylose; (17) acid from rhamnose; (18) acid from trehalose; (19) acid from inositol; (20) acid from mannitol; (21) acid from sorbitol; (22) nicotinamide as $\mathrm{N}$ and $\mathrm{C}$ sources.

"The characters that showed a positive match were $2,3,5,10,12,14,18,19,20,43,44,62,66,72,73,74$, 75,76 , and 77 (19 characters). The characters that showed a negative match were $1,4,9,21,22,30,32$, $33,37,40,42,46,81$, and 83 (14 characters). These numbers were counted omitting strain 71 ( $M$. intracellulare).

- The characters that showed a positive match were $3,10,14,18,19,47$, and additional characters $1,2,3$, and 9 (see footnote $c$ ). The characters that showed a negative match were $1,4,9,21,30,32,33,37,40,42$, 46,81 , and additional characters $7,12,13$, and 22 (see footnote $c$ ).

ber of linked characters is minimal. This set gave the most clusters.

Previously, Tsukamura (22) divided the strains received as $N$. asteroides into two taxa, $N$. farcinica and $N$. asteroides (a strict sense). In the present study, the taxon $N$. asteroides could be divided into two subgroups, $\mathrm{A}$ and $\mathrm{B}$. After Tsukamura's previous study (22), Goodfellow (5) divided strains designated as $N$. asteroides into five subgroups, and Kurup and Schmitt (11) divided them into four subgroups. The identity of the clusters shown in the present 

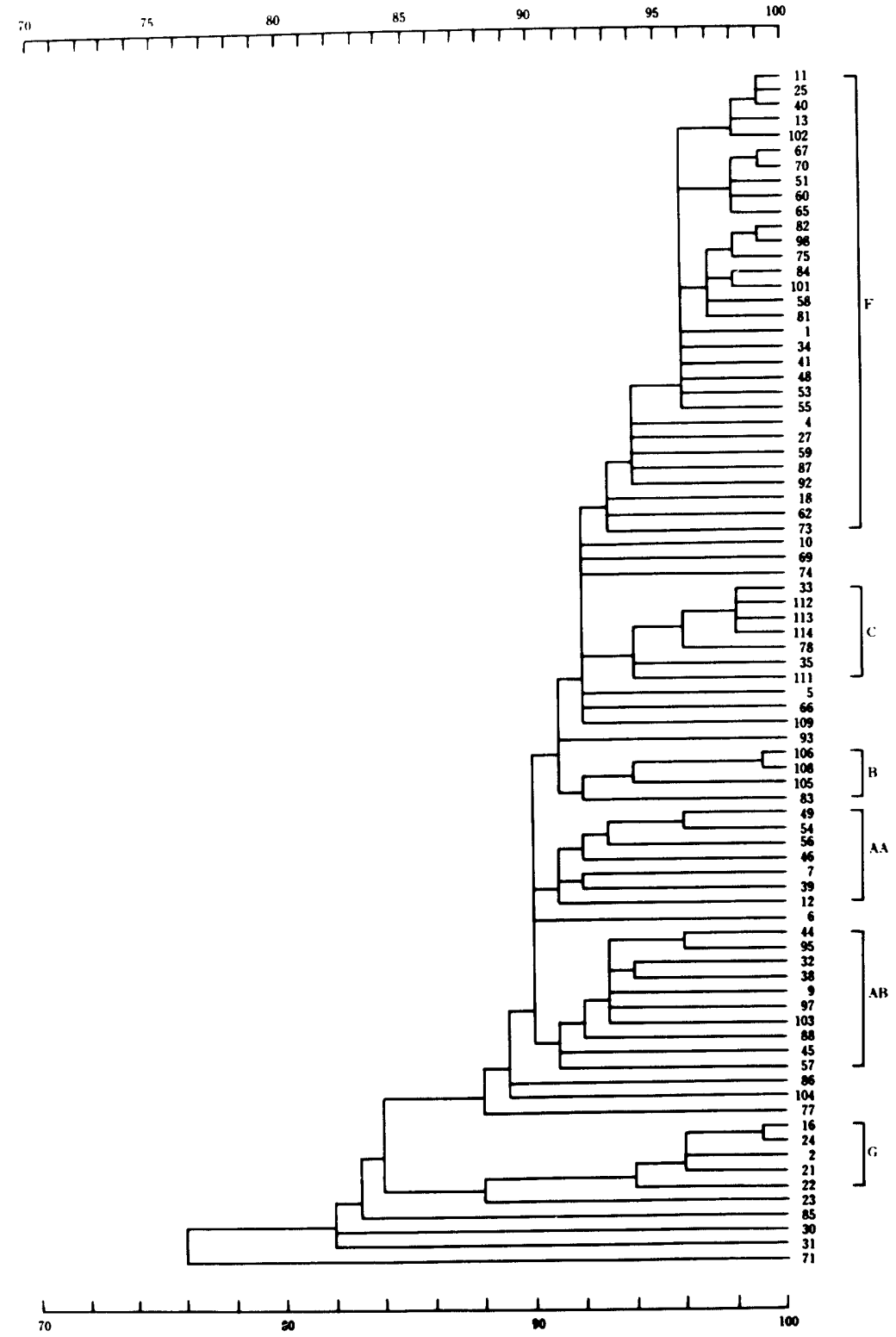

FIG. 1. Dendrogram obtained by the set A1. Abbreviations: F, N. farcinica; $C, N$. caviae; $B, N$. brasiliensis; $A A, N$. asteroides $A ; A B, N$. asteroides $B ; G$, G. lentifragmenta. 


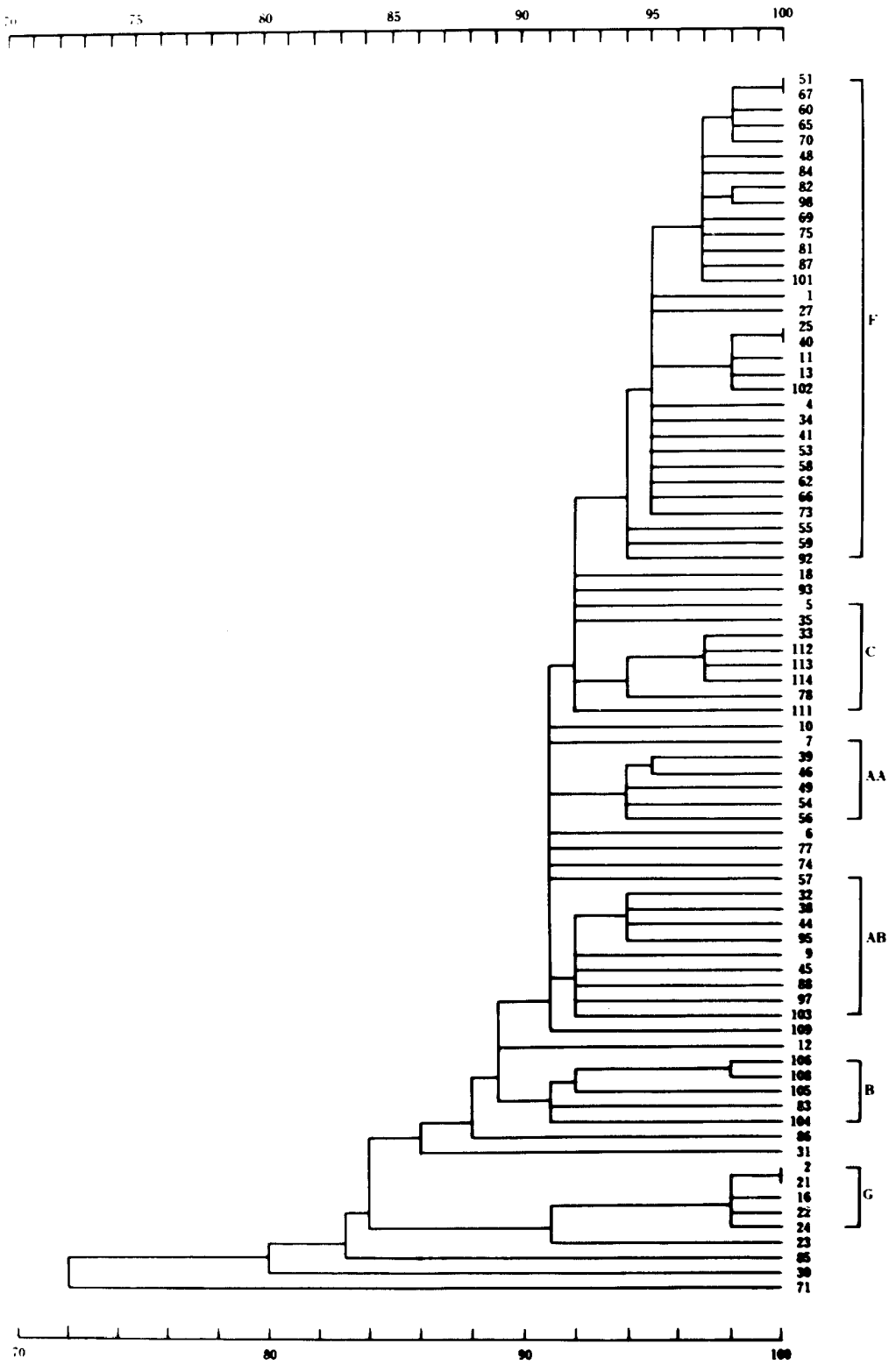

FIG. 2. Dendrogram obtained by the set A2. Abbreviations: $F, N$. farcinica; $C, N$. caviae; $A A, N$. asteroides $A ; A B, N$. asteroides $B ; B, N$. brasiliensis; $G, G$. lentifragmenta. 

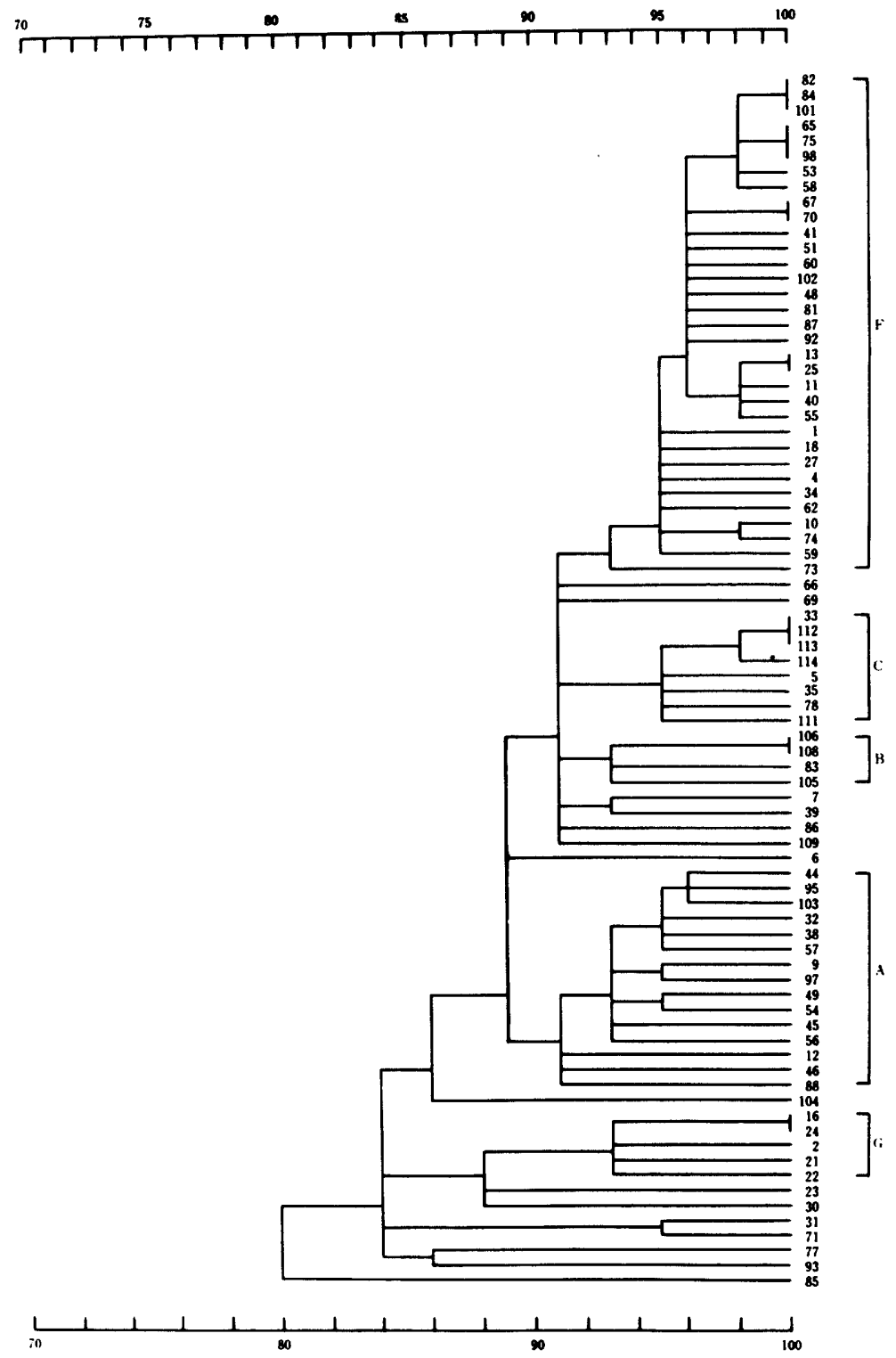

FIG. 3. Dendrogram obtained by the set A3. Abbreviations: $F, N$. farcinica; $C, N$. caviae; $B, N$. brasiliensis; $A, N$. asteroides (subgroups $A$ and $B$ in Fig. 1 are combined into one); $G$, G. lentifragmenta. 


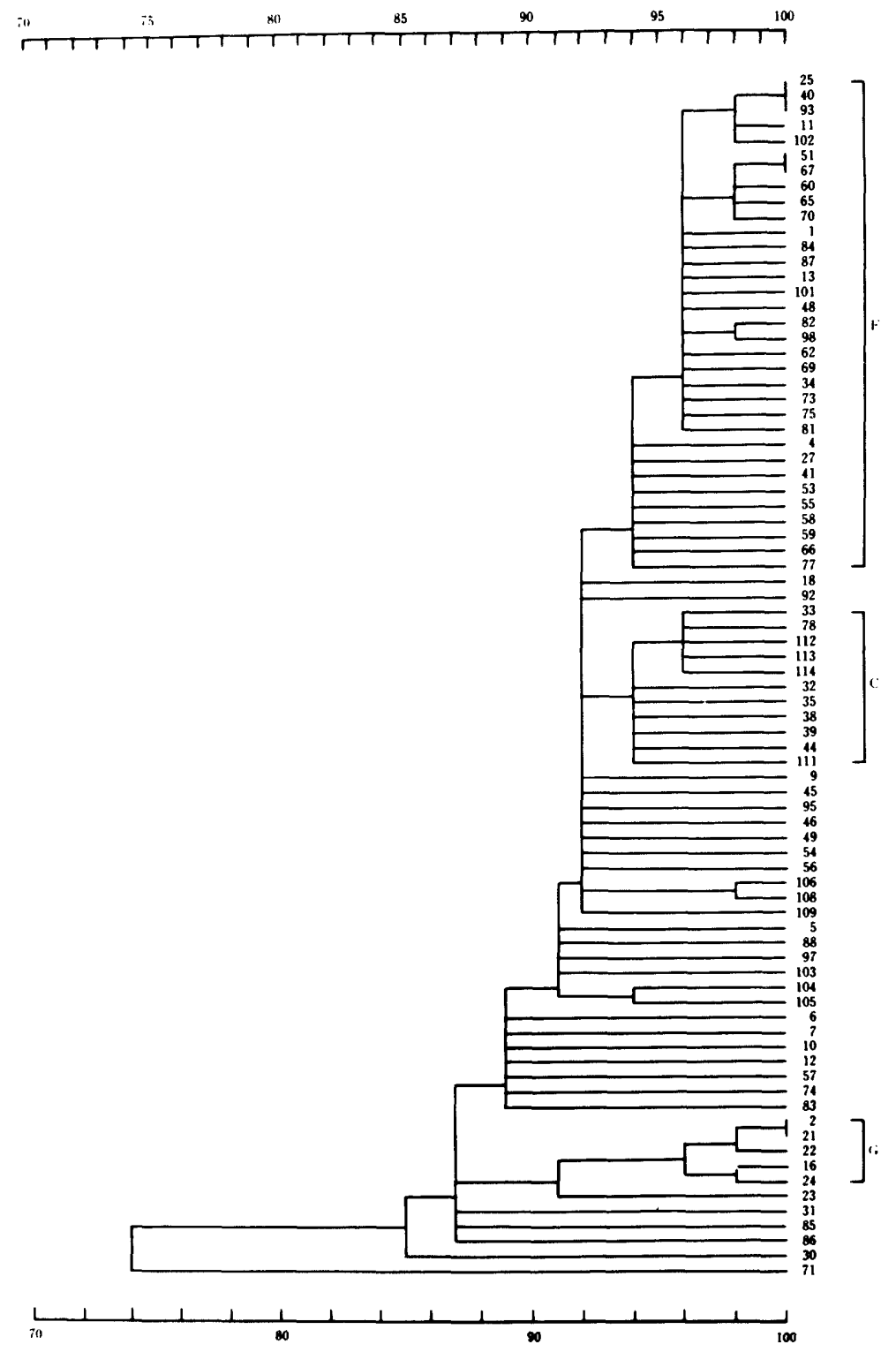

Fig. 4. Dendrogram obtained by the set A4. Abbreviations: $F, N$. farcinica; C, N. caviae; G, G. lentifragmenta. 


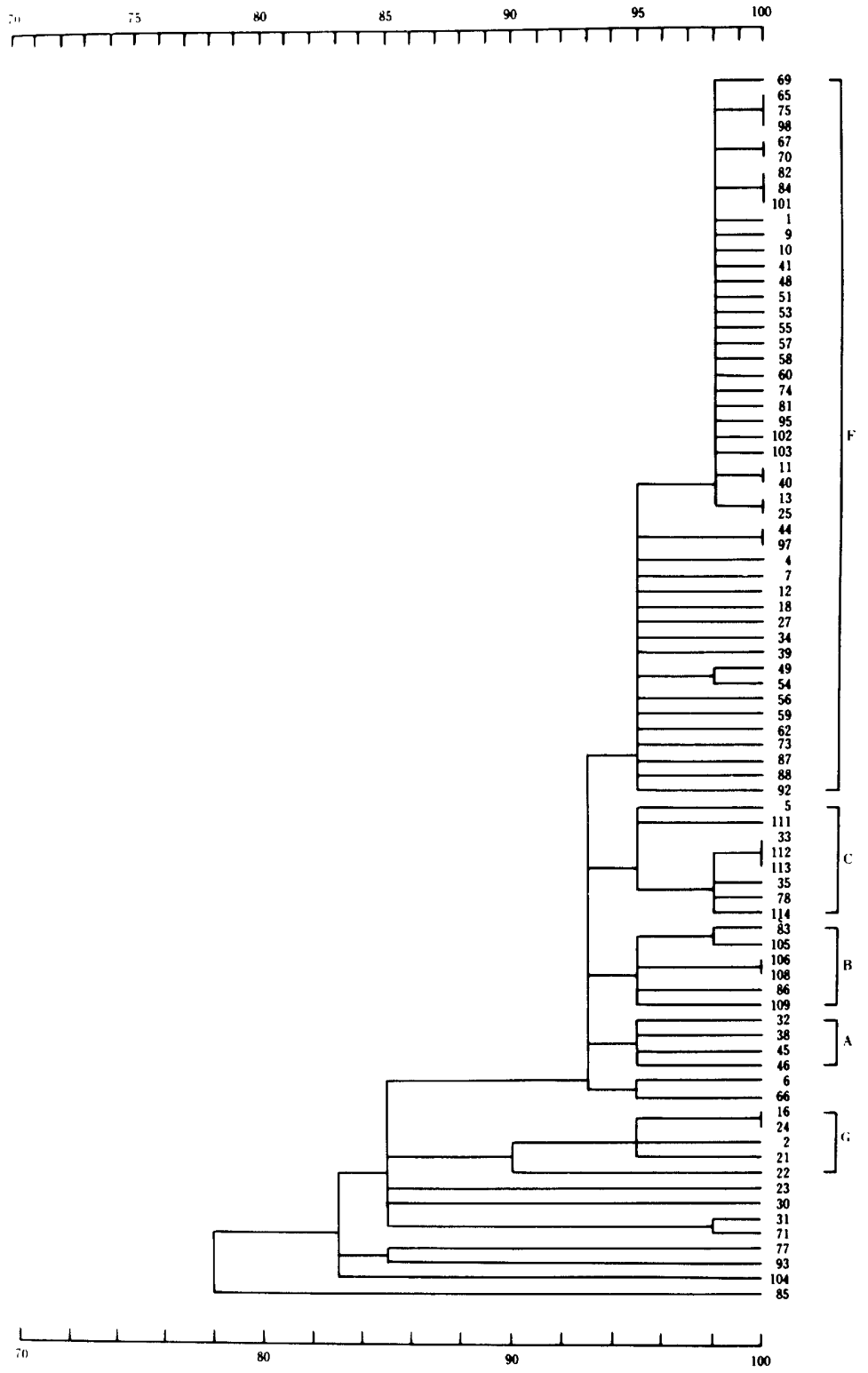

FIG. 5. Dendrogram obtained by the set A5. Abbreviations: F, N. farcinica; $C, N$. caviae; $B, N$. brasiliensis; A, N. asteroides; $G, G$. lentifragmenta. 


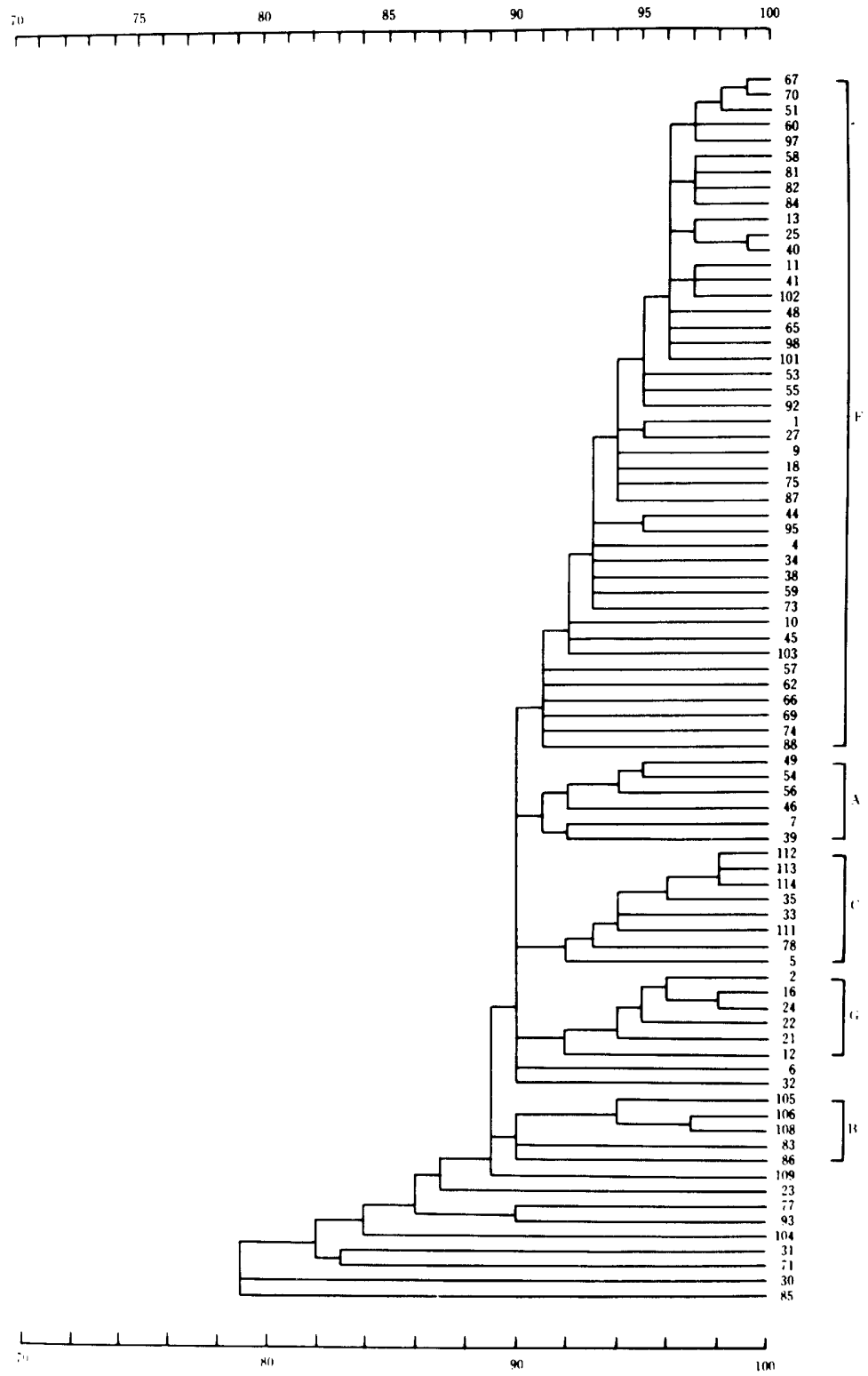

Fig. 6. Dendrogram obtained by the set B. Abbreviations: $F, N$. farcinica; $A, N$. asteroides (this cluster almost equals the cluster $N$. asteroides $A$ in Fig. 1); C, N. caviae; G, G. lentifragmenta; B, N. brasiliensis. Note: The cluster $N$. asteroides $B$ in Fig. 1 is included into the cluster $N$. farcinica. 
TABLE 4. Characters useful for distinguishing Nocardia species ${ }^{a}$

\begin{tabular}{|c|c|c|c|c|c|c|}
\hline Character & $\begin{array}{l}\text { N. farcin- } \\
\text { ica }\end{array}$ & $\begin{array}{l}\text { N. aster- } \\
\text { oides A }\end{array}$ & $\begin{array}{l}\text { N. aster- } \\
\text { oides B }\end{array}$ & $\begin{array}{l}\text { N. cav- } \\
\text { iae }\end{array}$ & $\begin{array}{l}\text { N. brasi- } \\
\text { liensis }\end{array}$ & $\begin{array}{c}\text { G. lentifrag } \\
\text { menta (for- } \\
\text { merly, } N \text {. } \\
\text { rubra) }\end{array}$ \\
\hline & $31^{b}$ & $7^{h}$ & $10^{b}$ & $7^{b}$ & $4^{b}$ & $5^{b}$ \\
\hline 1. Colony pigmentation in dark & 6 & 14 & 80 & 0 & 0 & 100 \\
\hline 2. Growth at $45^{\circ} \mathrm{C}$ & 100 & 0 & 0 & 29 & 0 & 0 \\
\hline 3. Tween hydrolysis (14 days) & 68 & 43 & 30 & 71 & 0 & 0 \\
\hline 4. $\alpha$-Esterase & 0 & 0 & 100 & 0 & 100 & 0 \\
\hline 5. $\beta$-Esterase & 77 & 14 & 100 & 100 & 100 & 0 \\
\hline 6. Acid phosphatase & 0 & 43 & 0 & 0 & 75 & 0 \\
\hline 7. $\beta$-Galactosidase & 100 & 100 & 100 & 100 & 100 & 0 \\
\hline 8. Nitrate reduction & 3 & 14 & 70 & 0 & 0 & 100 \\
\hline 9. Catalase (semiquantitative) & 29 & 0 & 50 & 71 & 75 & 60 \\
\hline 10. Acetamidase & 97 & 0 & 40 & 0 & 25 & 100 \\
\hline 11. Benzamidase & 68 & 0 & 0 & 0 & 0 & 0 \\
\hline 12. Urease & 100 & 100 & 70 & 100 & 100 & 0 \\
\hline 13. Allantoinase & 19 & 57 & 10 & 100 & 75 & 0 \\
\hline $\begin{array}{l}\text { 14. Growth on rifampin medium } \\
(25 \mu \mathrm{g} / \mathrm{ml})\end{array}$ & 97 & 86 & 90 & 100 & 100 & 0 \\
\hline $\begin{array}{l}\text { 15. Tolerance to ethambutol (5 } \\
\mu \mathrm{g} / \mathrm{ml})\end{array}$ & 100 & 86 & 100 & 100 & 100 & 0 \\
\hline 16. Sucrose as C source & 26 & 0 & 0 & 0 & 0 & 100 \\
\hline 17. $n$-Propanol as $\mathrm{C}$ source & 100 & 29 & 20 & 29 & 0 & 100 \\
\hline 18. Propylene glycol as $\mathrm{C}$ source & 55 & 0 & 10 & 0 & 0 & 100 \\
\hline 19. 1,3-Butylene glycol as C source & 77 & 0 & 0 & 0 & 0 & 20 \\
\hline 20. Mannose as $\mathrm{C}$ source & 100 & 29 & 10 & 100 & 75 & 100 \\
\hline 21. Galactose as C source & 0 & 0 & 0 & 0 & 100 & 0 \\
\hline 22. Rhamnose as C source & 81 & 0 & 0 & 0 & 0 & 0 \\
\hline 23. Trehalose as C source & 26 & 0 & 0 & 14 & 100 & 0 \\
\hline 24. Inositol as C source & 0 & 0 & 0 & 86 & 100 & 0 \\
\hline 25. Mannitol as $\mathrm{C}$ source & 0 & 0 & 0 & 100 & 100 & 100 \\
\hline 26. Sorbitol as $\mathrm{C}$ source & 0 & 0 & 0 & 29 & 0 & 100 \\
\hline 27. Citrate as $\mathrm{C}$ source & 6 & 86 & 0 & 0 & 100 & 100 \\
\hline 28. Benzoate as $\mathrm{C}$ source & 0 & 0 & 0 & 0 & 0 & 80 \\
\hline 29. Malonate as $\mathrm{C}$ source & 0 & 0 & 0 & 0 & 0 & 60 \\
\hline 30. L-Serine as $\mathrm{N}$ and $\mathrm{C}$ sources & 3 & 0 & 0 & 100 & 0 & 20 \\
\hline $\begin{array}{l}\text { 31. Glucosamine as } \mathrm{N} \text { and } \mathrm{C} \\
\text { sources }\end{array}$ & 94 & 57 & 0 & 100 & 75 & 80 \\
\hline 32. Acetamide as $\mathrm{N}$ and $\mathrm{C}$ source & 100 & 0 & 0 & 0 & 0 & 100 \\
\hline $\begin{array}{l}\text { 33. Monoethanolamide as } \mathrm{N} \text { and } \\
\mathrm{C} \text { source }\end{array}$ & 100 & 0 & 0 & 100 & 0 & 80 \\
\hline 34. Benzamide as $\mathrm{N}$ source & 61 & 0 & 70 & 0 & 0 & 0 \\
\hline 35. Nitrite as $\mathrm{N}$ source & 45 & 43 & 40 & 0 & 0 & 0 \\
\hline
\end{tabular}

${ }^{a}$ Values indicate the percentage of strains that showed a positive reaction.

${ }^{b}$ Number of strains tested (the strains that showed a compact cluster in Fig. 1).

study with those obtained by these authors will be a problem in further investigations. The relationship between the clustering and the kind of characters used in numerical classifications should also be studied in detail in the future.

\section{ACKNOWLEDGMENTS}

I thank S. Mizuno, H. Murata, and M. Oshima for their technical assistance, and S. Uchida, Sumitomo Machinery Co., for his kind help in the use of computers.

\section{REPRINT REQUESTS}

Address reprint requests to: Dr. M. Tsukamura, National Chubu Hospital, Obu, Aichi, Japan 474.

\section{LITERATURE CITED}

1. Berd, D. 1973. Nocardia asteroides. A taxonomic study with clinical correlations. Am. Rev. Respir. Dis. 108:909-917.

2. Bradley, S. G. 1973. Relationships among mycobacteria and nocardiae based upon deoxyribonucleic acid reassociation. J. Bacteriol. 113:645-651.

3. Cerbón, J. 1967. Taxonomic analysis of Nocardia. Rev. Latinoam. Microbiol. Parasitol. 9:65-68.

4. Franklin, A. A., Jr., and N. M. McClung. 1976. Heterogeneity among Nocardia asteroides strains. J. Gen. Appl. Microbiol. 22:151-159.

5. Goodfellow, M. 1971. Numerical taxonomy of some nocardioform bacteria. J. Gen. Microbiol. 69:33-80.

6. Gordon, R. E., and J. M. Mihm. 1957. A comparative study of some strains received as nocardiae. J. Bacteriol. 
$73: 15-27$.

7. Gordon, R. E., and J. M. Mihm. 1959. A comparison of Nocaria asteroides and Nocardia brasiliensis. J. Gen. Microbiol. 20:129-135.

8. Gordon, R. E., and J. M. Mihm. 1962. The type species of the genus Nocardia. J. Gen. Microbiol. 27:1-10.

9. Gordon, R. E., and J. M. Mihm. 1962. Identification of Nocardia caviae (Erikson) nov. comb. Ann. N. Y. Acad. Sci. 98:628-636.

10. Holm, P. 1975. Seven cases of human nocardiosis caused by Nocardia farcinica. Sabouraudia 13:161-169.

11. Kurup, P. V., and J. A. Schmitt. 1973. Numerical taxonomy of Nocardia. Can. J. Microbiol. 19:1035-1048.

12. Lechevalier, M. P., A. C. Horan, and H. Lechevalier. 1971. Lipid composition in the classification of nocardiae and mycobacteria. J. Bacteriol. 105:313-318.

13. Lockhart, W. R. 1967. Factors affecting reproducibility of numerical classifications. J. Bacteriol. 94:826-831.

14. Magnusson, M., and F. Mariat. 1968. Delineation of Nocardia farcinica by delayed type skin reactions on guinea pigs. J. Gen. Microbiol. 51:151-158.

15. Ridell, M., and M. Norlin. 1973. Serological study of Nocardia by using mycobacterial precipitation reference systems. J. Bacteriol. 113:1-7.

16. Sneath, P. H. A. 1964. New approaches to bacterial taxonomy: use of computers. Annu. Rev. Microbiol. 18:335-346.

17. Sneath, P. H. A. 1972. Computer taxonomy, p. 29-98. In
J. R. Norris and D. W. Ribbons (ed.), Methods in microbiology. Academic Press Inc., London.

18. Sokal, R., and P. H. A. Sneath. 1963. Principles of numerical taxonomy. W. H. Freeman and Co., San Francisco.

19. Tsukamura, M. 1966. Adansonian classification of mycobacteria. J. Gen. Microbiol. 45:253-273.

20. Tsukamura, M. 1967. Identification of mycobacteria. Tu bercle 48:311-338.

21. Tsukamura, M. 1969. Identification of group II scotochromogens and group III nonphotochromogens of mycobacteria. Tubercle 50:51-60.

22. Tsukamura, M. 1969. Numerical taxonomy of the genus Nocardia. J. Gen. Microbiol. 56:265-287.

23. Tsukamura, M. 1975 . Numerical analysis of the relationship between Mycobacterium, rhodochrous group, and Nocardia by use of hypothetical median organisms. Int. J. Syst. Bacteriol. 25:329-335.

24. Tsukamura, M. 1976. Numerical classification of slowly growing mycobacteria. Int. J.Syst. Bacteriol. 26:409-420.

25. Tsukamura, M. 1976. Conditions for normal distribution of matching coefficients involved in a cluster in numerical classification. Jpn. J. Micribiol. 20:357-359.

26. Tsukamura, M., S. Mizuno, and H. Murata. 1975. Numerical taxonomy study of the taxonomic position of Nocardia rubra reclassified as Gordona lentifragmenta Tsukamura nom.nov. Int. J. Syst. Bacteriol. 25:377-382. 